system that both prepares and protects people seeking to invest in themselves through postsecondary education, should be high on the national policy agenda.

DOI: http://dx.doi.org/ıo.6oI7/ihe.20I8.93.1038I

\section{Income-Contingent Loans: Not a Miracle Solution}

\section{Ariane de Gayardon}

Ariane de Gayardon is researcher at the Institute of Education Centre for Global Higher Education, University College London, UK. E-mail: a.gayardon@ucl.ac.uk.

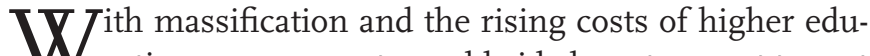
cation, governments worldwide have to resort to cost sharing to alleviate the weight of higher education funding on the state. With the rise of tuition fees, however, governments have to structure financing options ensuring that students from all walks of life have the opportunity to access higher education. This has led to the creation of government-guaranteed student loans.

While individuals are able to take up loans from private banks to finance different products like homes and cars, higher education is rarely one of them. Investing in students is indeed a risky investment for banks given high noncompletion rates and the impossibility of taking back the product invested in-like taking possession of a home when a mortgage is no longer being repaid. For these reasons, governments have to be heavily involved in the provision of student loans.

\section{InCOME-CONTINGENT LOANS}

Government loans for education usually take one of two forms: a mortgage-style loan or an income-contingent loan (ICL). In the case of a mortgage-style loan, the individual has to repay the total amount of his/her loan plus interest during a set period of time, leading to mandatory fixed monthly payments. The main disadvantage of this type of loan is that higher education is no guarantee that one will have the means to repay-these loans can lead to repayment hardship, default, and subsequently credit reputation loss.

ICLs are designed to propose a fairer option for students. Repayment of the loans is tied to income, with individuals repaying a share of their income, usually for a fixed amount of time. This insures against high repayment burdens. It also eliminates default, as governments automatically forgive outstanding balances once the payment period is over: this is called the "hidden grant." For these reasons, ICLs have many advocates across the world: they are seen as a way to provide free higher education at the point of entry and ensure a smooth and equitable repayment.

\section{What Is Currently Happening?}

In 2017 , however, there were increasingly heightened debates on the financing of higher education in three flagship countries for ICLs: Australia, England, and New Zealand. Examining the relevant issues and learning from them is important at a time when student debt is rising, leading to a revival of the concept of free-tuition higher education.

Australia is at a political standstill over higher education financing because of the balance of power in the senate, which has been unable to pass any legislation on higher education financing since 20I3. Failed legislative proposals in recent years include fees deregulation, reducing the income repayment threshold, and introducing a student loan fee. These proposals all aimed at reducing the expenses of the Higher Education Loan Program (HELP) to ensure its sustainability. In December 20I7, the government took a radical measure by including higher education financing

\section{What the examples of these three coun- tries show us is that systems with ICLs are also prone to issues and question- able policy decisions.}

reforms in the 2018 budget. The reforms lowered the repayment threshold by AU\$ II, O०० (US\$9,000), which will negatively impact individuals with lower incomes, and froze university budgets for two years, reducing institutional ability to fund students. The decision of the Australian government to pass these changes as part of the budget is a direct testimony of its inability to sustain the current system.

England has also been overwhelmed by debates on higher education financing since the Labour Party regained popularity thanks to a proposal to make higher education tuition free, a sign of the general discontent with the high cost of higher education and increasing levels of student loan debt. Among the issues under discussion in England: the fact that the financial protection afforded by ICLs has led to an inflation of the cap on tuition fees, from $£$ I, , ० (US\$1,400) means-tested in I998 to $£$ 9,250 (US\$13,000) for all in 20I7. The high rate of interest (up to 3 percent plus inflation) that is in effect during the student's course of study also contributes to increased debt levels and angry loan recipients. Additionally, as of 2016 , grants have completely disappeared and been replaced by loans-a financial move to reduce the national deficit. As a result, low-income 
students are now those graduating with the highest debtquite a regressive system. One last issue worth mentioning is the collapse of the number of part-time students since the cap on tuition fees was raised in 20I2, showing the inadequacy of the financial aid system for this type of student. Several changes have already been made, including raising the repayment threshold to alleviate debt burden, but a major review of higher education is in the works, and most experts agree that it should lead to definitive changes in the English financing system, with, very probably, a lowering of tuition fees.

Finally, New Zealand has also been struggling with student loan debt and its ICL system, as evidenced by contradictory policies on interest adopted in the 2000 s and an increase in the rate of repayment from io percent to I2 percent-far higher than in England (9 percent) and Australia (up to 8 percent). This debate concluded with the election of the current government in $20 \mathrm{I} 7$, which is committed to introducing tuition-free higher education, a radical move away from ICLs.

\section{Lessons from Australia, England, and New Zealand}

What the examples of these three countries show us is that systems with ICLs are also prone to issues and questionable policy decisions. These national cases also demonstrate the need for flexibility in the implementation and specifications of ICLs, to be able to adapt the system to a changing economic and social context. Additionally, no ICL system exists without some government subsidization of those loans that are never repaid in full. This must be part of the design from the start, with a conscious decision by the government to subsidize students in this way.

What is also easy to forget, when considering how ICLs fit economically in the current higher education context, is that an ICL is still a loan. Not only does it mean that the borrower's take home pay is lowered by loan repayment, it also has psychological implications tied to the mere concept of debt. Debt aversion, in particular, is strong among individuals from low socioeconomic backgrounds. If ICL is the only financial option, participation from these strata of society could drop. These individuals are also less likely to repay their loans in full, and will end up being subsidized by the government. This highlights the necessity of designing a fair financial aid system, achieving a balance between a means-tested grant system and a well-designed ICL system, to best accommodate all types of students.

DOI: http://dx.doi.org/ıo.6oI7/ihe.2018.93.10373

\section{African Private Higher Edu- cation: Progressive Policies and Ambivalent Stances}

\author{
Wondwosen Tamrat and Damtew Teferra
}

Wondwosen Tamrat is associate professor and founding president of St. Mary's University, Ethiopia. E-mails: preswond@smuc.edu.et and wondwosentamrat@gmail.com. Damtew Teferra is professor of higher education, leader of Higher Education and Training Development, University of KwaZulu-Natal, South Africa, and founding director of the International Network for Higher Education in Africa. E-mails: teferra@ ukzn.ac.za and teferra@bc.edu.

$\mathrm{T}$ he rise of private higher education (PHE) in Africa has been mainly driven by such factors as the inability of the public sector to meet growing demands, strain on public finance that called for alternative sources of funding, and consequent economic policies that led to structural reforms. By global standards, the growth of the PHE sector in Africa remains low-currently hovering around 20 percent of the overall tertiary enrollment. However, the sector's importance is strongly felt in terms of addressing the deficiencies of the public sector, creating job opportunities, enhancing managerial efficiencies, and infusing an entrepreneurial culture into the traditionally conservative higher education arena. The significant role governments play through appropriate legislation and policies remains one of the most critical levers for lending credence to, and advancing the growth of, the PHE sector. However, arguments against PHE have been equally strong due to a host of controversies surrounding the use of taxpayers' money on private institutions.

We argue that while direct support to PHE could be difficult and in most cases controversial, an indirect form of support to PHEIs, even in resource-depleted contexts like Africa, could help the sector thrive. This type of support, some of which we consider progressive, could come in various forms, as regional experiences discussed here indicate.

\section{LOANS AND SCHOLARSHIPS}

Loans to students and/or institutions are common forms of support to PHEIs, though instituting efficient mechanisms in Africa has not been particularly easy. In Kenya, students from chartered private universities benefit from loans disbursed by the Higher Education Loans Board. In Ghana, the Student Loan Trust Fund provides loans to students enrolled at accredited institutions-including PHEIs. Lesotho's interest-free Loan Bursary Fund is open to all students who have obtained admission to HEIs. Botswana provides student loans and scholarships to privately enrolled stu- 